\title{
PENGARUH KOMPENSASI, LINGKUNGAN KERJA DAN DISIPLIN KERJA TERHADAP KINERJA KARYAWAN PADA PT. STRATEGI INISIATIF MEDIA JAKARTA
}

\author{
Hendri Jopanda \\ Dosen Tetap Program S1 Jurusan Manajemen Fakultas Ekonomi Universitas Satya Negara Indoneisia \\ hjopanda@yahoo.com
}

ABSTRACT

This study aims to determine the effect of compensation, work environment, and work discipline on the performance of employees of PT. Media Initiative Strategy. Determination of the sample in this study using a sample of 46 respondents and this study uses multiple linear regression method. The results of this study indicate that partially compensation has a significant effect on the performance of employees of PT. Media Initiative Strategy with tcount 3.889> $t$ table 1.682 and significant value $0.000<0.05$, work environment has a significant effect on the performance of employees of PT. Media Initiative Strategy with tcount of $-3.447<t$ table 1.682 and significant value $0.001<0.05$ and work discipline have a significant effect on the performance of employees of PT. Media Initiative Strategy with tcount of $-3.237<t$ table 1.682 and significant value $0.002<0.05$. While simultaneously showing that compensation, work environment, and work discipline simultaneously affect the performance of employees of PT. Media Initiative Strategy with Fcount 9.199> Ftable 2,827 and significant value 0,000<0.05.

Keywords: Compensation, Work Environment, Work Discipline Against Employee Performance.

\section{Pendahuluan}

Pada era globalisasi saat ini banyak perusahaan yang dituntutuntuk dapat memaksimalkan kinerja karyawan.Hal ini berarti bahwaperusahaan harus mampu menganalisis faktor-faktor yang dapatmempengaruhi kinerja karyawan. Dalam mengatasi hal tersebut sumber dayamanusia (SDM) adalah paling utama yang harus diperhatikanperkembangannya karena dengan adanya SDM yang baik dan professionalakan sangat membantu dalam memaksimalkan kinerja dalam suatuperusahaan.

Kinerja pada umumnya diartikan sebagai kesuksesan seorang dalam melaksanakan suatu pekerjaan.Menurut Rivai dan Sagala dalam Donni Juni Priansa (2017:48) menyatakan bahwa kinerja adalah perilaku nyata yang ditampilkan setiap orang sebagai prestasi kerja yang dihasilkan oleh pegawai sesuai dengan perannya dalam perusahaan.

Persentase Menurunnya Kinerja Karyawan Pada Pt. Strategi Inisiatif Media Jakarta

Tabel 1.1

\begin{tabular}{|c|c|}
\hline Tahun & Presentase Kinerja Karyawan (\%) \\
\hline 2015 & $\mathbf{9 0 , 0 \%}$ \\
\hline 2016 & $\mathbf{8 4 , 5 \%}$ \\
\hline 2017 & $\mathbf{7 9 , 0 \%}$ \\
\hline
\end{tabular}

Sumber: PT. Strategi Inisiatif Media 
Hal tersebut dapat dilihat dari persentase dari tahun 2015 sebesar 90,0\%, tahun 2016 sebesar 84,5\%, dan tahun 2017 sebesar 79,0\%.Kinerja karyawan pada PT. Strategi Inisiatif Media mengalami penurunan di duga dikarenakan faktor kompensasi, lingkungan kerja dan disiplin kerja.Akibatnya perusahaat ini kalah saing dengan perusahaan lainnya.

Pertama faktor yang mempengaruhi kinerja karyawan pada PT. Strategi Inisiatif Media adalah faktor kompensasi.Menurut Edwin B. Flippo dalam R. Supomo (2018:95) kompensasi didefinisikan sebagai balas jasa yang adil dan layak diberikan kepada paa pekerja atas jasajasanya dalam mencapai tujuan organisasi. Pada PT. Strategi Inisiatif Media, banyak pegawai yang merasa tidakpuasan dalam bekerja, hal ini dikarenakan seperti pemberian bonus dan penghargaan yang kurang dari hasil kerja karyawan.

Kemudian yang kedua, yang menyebabkan menurunnya kinerja karyawan adalah lingkungan kerja. Menurut Sutrisno (2016:118) lingkungan kerja adalah keseluruhan sarana dan prasarana kerja yang ada disekitar karyawan yang sedang melakukan pekerjaan yang dapat memengaruhi pelaksanaan pekerjaan.Kurangnya fasilitas yang diberikan pada PT. Strategi Inisiatif Media, seperti penerangan, ruang kerja yang kurang nyaman, peralatan kerja yang kurang lengkap. Lingkungan yang kurang nyaman akan berpengaruh menurunnya terhadap kinerja karyawan. Karena lingkungan kerja yang kurang nyaman akan membuat karyawan menjadi kurang bersemangat untuk bekerja dan akan menyebabkan menurunnya kinerja karyawan.

Lingkungan kerja adalah salah satu faktor yang mampu mempengaruhi kepuasan kerja karyawan, dari keberhasilan dalam melaksanakan suatu pekerjaan tetapi juga dapat menyebabkan suatu kegagalan di dalam pelaksanaan suatu pekerjaan, karena ruang kerja dapat mempengaruhi pekerja, terutama lingkungan kerja yang bersifat psikologis sedangkan pengaruh itu sendiri dapat bersifat positif atau negatif.

Dan yang terakhir yang mempengaruhi menurunnya kinerja adalah disiplin kerja.Menurut Sastrohadiwiryo Siswanto dalam R. Supomo (2018:133) disiplin kerja dapat didefinisikan sebagai suatu sikap menghargai, menghormati, patuh, dan taat terhadap peraturan-peraturan yang berlaku baik secara tertulis maupun yang tidak tertulis serta sanggup menjalankan dan tidak mengelak untuk menerima sanksi-sanksi apabila melanggar tugas dan wewenang yang diberikan kepadanya. Menurunnya disiplin kerja pada PT. Strategi Inisiatif Media dapat memicu dampak negatif yang pada akhirnya akan menyebabkan kinerja karyawan menjadi menurun. Hal-hal yang menyebabkan disiplin kerja menurun pada PT. Strategi Inisiatif Media antara lain adalah masih tingginya absensi karyawan yang sering terlambatnya karyawan masuk kantor dan pulang lebih cepat dari jam yang sudah ditentukan, serta tidak tercapainya program kerja yang sudah ditargetkan dari atasan kepada bawahan.

Karena terdapat fenomenamasalah pada PT. Strategi Inisiatif Mediadan perbedaan hasil penelitian tersebut maka peneliti tertarik untuk mengangkat masalah tersebut untuk diteliti dan membuktikan hasil penelitian yang sebelumnya. Motivasi, Lingkungan Kerja, dan Disiplin Kerja seorang karyawan tentuakan sangat berpengaruhterhadap kinerja karyawan. Untuk itu dilakukan penelitian berjudul "Pengaruh Kompensasi, Lingkungan Kerja, dan Disiplin Kerja terhadap Kinerja Karyawan pada PT. Strategi Inisiatif Media Jakarta”.

\section{Tinjauan Pustaka}

Menurut Donni Juni Priansa (2017:48) kinerja dalam bahasa inggris disebut dengan job performance atau actual performance atau level of performance, yang merupakan tingkat keberhasilan pegawai dalam menyelesaikan pekerjaannya. Kinerja merupakan perwujudan dari 
bakat atau kemampuan dalam bentuk karya nyata atau merupakan hasil kerja yang dicapai pegawai dalam mengembankan tugas dan pekerjaan yang berasal dari perusahaan.

Menurut Anwar Prabu Mangkunegara (2013:67) pengertian kinerja (prestasi kerja) adalah hasil kerja secara kualitas dan kuantitas yang dicapai oleh seseorang pegawai dalam melaksanakan tugasnya sesuai dengan tanggung jawab yang diberikan kepadanya.

Menurut Lijan Poltak Sinambela (2016:480) mengemukakan bahwa kinerja pegawai dedefinisikan sebagai kemampuan pegawai dalam melakukan sesuatu keahlian tertentu.

Berdasarkan definisi dari beberapa pendapat di atas dapat disimpulkan kinerja karyawan adalah tingkat keberhasilan pegawai dalam menyelesaikaan pekerjaannya secara kualitas dan kuantitas sesuai dengan tanggung jawab dan keahlian tertentu.

Menurut Wibowo (2016:289) kompensasi merupakan kontra prestasi terhadap pengguna tenaga atau jasa yang telah diberikan oleh tenaga kerja. Kompensasi merupakan jumlah paket yang ditawarkan organisasi kepada pekerja sebagai imbalan atau penggunaan tenaga kerja.

Menurut Donni Juni Priansa (2017:291) kompensasi merupakan salah satu alasan dan motivasi utama seorang pegawai bekerja di suatu perusahaan. Pegawai menggunakan pengetahuan, keterampilan, tenaga, waktu, serta komitmennya semata-mata unruk membaktikan atau mengabdikan diri pada perusahaan, melainkan mengharapkan imbalan atau balas jasa atas kinerja dan produktivitas kerja yang dihasilkan.

Menurut Arif Yusuf Hamali (2016:78) kompensasi merupakan salah satu fungsi yang penting dalam manajemen sumber daya manusia. Kasus yang terjadi dalam hubungan kerja mengandung masalah kompensasi dan berbagai segi yang terkait, seperti tunjangan, kenaikan kompensasi, struktur kompensasi, dan skala kompensasi. Kompensasi dimaksudkan sebagai balas jasa (reward) perusahaan terhadap pengorbanan waktu, tenaga, pikiran yang telah diberikan karyawan kepada perusahaan.

Berdasarkan definisi dari beberapa pendapat di atas dapat disimpulkan kompensasi merupakan kontra prestasi terhadap pengguna tenaga kerja atau jasa yang diberikan dan sebagai motivasi utama seorang pegawai bekerja di suatu perusahaan berbagai segi yang terkait, seperti tunjangan, kenaikan kompensasi, struktur kompensasi, dan skala kompensasi.

Menurut Kasmir (2016:192) lingkungan kerja merupakan suasana atau kondisi di sekitar lokasi tempat bekerja. Lingkungan kerja dapat berupa ruangan, layout, sarana dan prasarana serta hubungan kerja dengan sesama dengan rekan kerja.

Menurut C. Roland Cristensen dalam Supomo (2018:18) lingkungan kerja merupakan pola semua kondisi-kondisi eksternal dan pengaruh-pengaruh yang memengaruhi kehidupan dan pengembangan perusahaan.

Nitisemito dalam Nuraini (2013:97) lingkungan kerja adalah segala sesuatu yang ada disekitar karyawan dan dapat mempengaruhi dalam menjalankan tugas yang diembankan kepadanya misalnya dengan adanya air conditioner (AC), penerangan yang memadai dan sebagainya.

Berdasarkan definisi dari beberapa pendapat di atas dapat disimpulkan bahwa lingkunga kerja adalah suatu kondisi di tempat kerja yang dapat mempengaruhi dalam menjalankan tugas atau pekerjaan, berupa ruangan, layout, AC, dan penerangan.

Edy Sutrisno (2014: 89) menjelaskan bahwa disiplin kerja adalah perilaku seseorang yang sesuai dengan peraturan, prosedur kerja yang ada, atau disiplin adalah sikap tingkah laku dan perbuatan yang sesuai dengan peraturan organisasi baik tertulis maupun tidak tertulis. 
Menurut Arif Yusuf Hamali (2016:214) disiplin kerja adalah sesuatu kekuatan yang berkembang di dalam tubuh karyawan dan menyebabkan karyawan dapat menyesuaikan diri dengan sukarela pada keputusan peraturan, dan nilai-nilai tinggi dari pekerjaan dan perilaku.

Menurut Siagian dalam Edy Sutrisno (2016:86) disiplin kerja berarti tindakan yang diambil dengan penyeliaan untuk mengoreksi perilaku dan sikap yang salah pada sementara karyawan.

Berdasarkan definisi dari beberapa pendapat di atas dapat disimpulkan disiplin kerja adalah perilaku seseorang yang sesuai dengan peraturan, karyawan dapat menyesuaikan diri dengan sukarela pada keputusan peraturan dan tindakan penyelia untuk perilaku dan sikap karyawan.

\section{METODOLOGI PENELITIAN}

\section{Variabel}

Variable tersebut terbagi dalam dua jenis variable, yaitu variable dependen atau terikat dan variable (Y) dan variable idependen atau bebas $(\mathrm{X})$.

1. Variable dependen atau terikat (Y)

Variabel terikat adalah variabel yang diduga sebagai akibat atau yang dipengaruhi oleh variabel yang mendahuluinya, yakni variabel bebas (independen) (Soewadji, 2012:115). Variabel terikat dalam penelitian ini adalah:

Kinerja Karyawan (Y)

Menurut Prawirosentono dalam Lijan Poltak Sinambela (2016:481) kinerja adalah hasil kerja yang dapat dicapai oleh seseorang atau sekelompok orang dalam suatu organisasi, sesuai dengan wewenang dan tanggung jawab masing-masing, dalam rangka upaya mencapai tujuan organisasi bersangkutan secara legal, tidak melanggar hukum dan sesuai dengan moral dan etika.

2. Variable independen atau bebas (X)

Variabel bebas adalah variabel menentukan atau yang mempengaruhi adanya variabel yang lain (Soewadji, 2012:115). Variabel bebas dalam penelitian ini adalah:

- $\mathrm{X}_{1}$ : Kompensasi

- $\mathrm{X}_{2}$ : Lingkungan kerja

- $\mathrm{X}_{3}$ : Disiplin kerja

a. Kompensasi $\left(\mathrm{X}_{1}\right)$

Menurut Hasibuan (2013:118) Kompensasi adalah semua pendapatan yang berbentuk uang, barang langsung atau tidak langsung yang diterima pegawai sebagai imbalan atas jasa yang diberikan kepada perusahaan.

b. Lingkungan Kerja $\left(\mathrm{X}_{2}\right)$

Menurut Silalahi (2013:188) mengemukakan bahwa lingkungan kerja adalah keseluruhan elemen-elemen bik didalam maupun diluar batas organisasi, baik yang berdampak secara langsung maupun tidak langsung terhadap aktivitas manajerial untuk mencapai tujuan organisasi.

c. Disiplin Kerja $\left(\mathrm{X}_{3}\right)$

Menurut Singodimedjo dalam Edy Sutrisno (2016:86), mengatakan disiplin kerja adalah sikap kesediaan dan kerelaan seseorang untuk mematuhi dan menaati norma-norma peraturan yang berlaku di sekitarnya. 


\section{Skala Pengukuran}

Menurut Soewadji (2012:160) skala pengukuran adalah salah satu kegiatan yang harus dilakukan dalam proses pengumpulan data. Apakah metode yang dipergunakan dalam pengumpulan data itu menggunakan metode observasi, angket, test interview, eksperimen ataupun kepustakaan pengukuran data harus dilakukan. Skala yang penulis pakai untuk skripsi ini adalah skala likert.

Menurut Soewadji (2012:167) skala likert adalah skala yang digunakan dalam pengukuran skala ordinal.Skala ini ingin membedakan intensitas sikap atau perasaan seseorang terhadap suatu hal tertentu. Nama skala ini diambil dari nama Rensis Likert yang diciptakan pada tahun 1932.

Untuk jawaban negatif atau tidak puas likert memberi skor dari yang paling kecil sampai yang paling besar, berikut contoh untuk pernyataan berskala likert beserta skor untuk jawaban seperti tertera dibawah ini.

\section{Sampel Penelitian}

\section{Populasi}

Menurut Sugiyono (2015:148) populasi adalah wilayah generalisasi yang terdiri atas objek atau subjek yang mempunyai kuantitas dan karakteristik tertentu yang ditetapkan oleh penelitian untuk dipelajari dan kemudian ditarik kesimpulannya.Populasi dalam penelitian ini adalah 46 orang karyawan PT. Strategi Inisiatif Media.

\section{Sampel}

Menurut Sugiyono (2015:156) sampel adalah bagian dari jumlah dan karakteristik yang dimiliki oleh populasi dan harus bersifat representative (mewakili).Untuk menentukan berapa minimal sampel yang dibutuhkan jika ukuran populasi diketahui dapat digunakan rumus Sampling Jenuh.Sampling jenuh adalah teknik penentuan sampel bila semua anggota populasi digunakan sebagai sampel.Hal ini sering dilakukan bila jumlah populasi relatif kecil atau kurang dari 100 orang.

\section{ANALISIS DAN HASIL PEMBAHASAN}

\section{Hasil Uji Deskriptif}

\begin{tabular}{|l|r|r|r|r|r|}
\hline & N & \multicolumn{1}{|c|}{ Minimum } & \multicolumn{1}{c|}{ Maximum } & \multicolumn{1}{c|}{ Mean } & \multicolumn{1}{c|}{ Std. Deviation } \\
\hline Kompensasi & 46 & 52 & 80 & 66.74 & 6.638 \\
Lingkungan Kerja & 46 & 45 & 80 & 67.24 & 7.131 \\
Disiplin Kerja & 46 & 46 & 75 & 59.76 & 7.409 \\
Kinerja Karyawan & 46 & 49 & 75 & 61.15 & 6.596 \\
Valid N (listwise) & 46 & & & \\
\hline
\end{tabular}

Pada table di atas dapat dilihat variabel kompensasi memiliki nilai terendah sebesar 52 dan nilai tertinggi sebesar 80 dengan nilai rata-ratanya sebesar 66.74 dan standar deviasinya (tingkat sebaran datanya) sebesar 6.638. Variabel lingkungan kerja memiliki nilai terendah 45 dan nilai tertinggi sebesar 80 dengan nilai rata-ratanya sebesar 67.24 dan tingkat sebaran datanya sebesar 7.131. Variabel disiplin kerja memiliki nilai terendah 46 dan nilai tertinggi sebesar 75 dengan nilai rata-ratanya sebesar 59.76 dan tingkat sebaran datanya sebesar 7.409. Variabel kinerja karyawan memiliki nilai terendah 49 dan nilai tertinggi 75 dengan nilai rata-rata sebesar 61.15 dan tingkat sebaran datanya sebesar 6.596 . 


\section{Uji Validitas}

Menurut Priyatno (2014:51) uji validtas merupakan uji instrument data untuk mengetahui seberapa cermat suatu item dalam apa yang ingin diukur. Item dapat dikatakan valid jika adanya korelasi yang signifikan dengan skor totalnya.

Uji signifikansi dengan membandingkan nilai $r_{\text {hitung }}$ dengan nilai $r_{\text {tabel }}$ untuk degree of freedom $(d f)=\mathrm{n}-\mathrm{k}$, dalam hal ini (n) merupakan jumlah sampel. Pada penelitian ini jumlah sampel $(n)=46$ dan besarnya $\mathrm{df}$ dapat dihitung 46-2 dengan $\mathrm{df}=44$ dan alpha $=0,05$ didapat $\mathrm{r}$

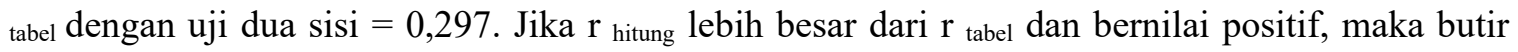
pernyataan atau indikator tersebut, dinyatakan valid (Priyatno, 2014).Hasil uji validitas pada indikator-indikator penelitian ini dapat dilihat dalam tabel berikut ini.

\section{Uji reliabilitas}

Menurut Priyatno (2014:64) Uji reliabilitas digunakan untuk mengetahui keajegan atau konsistensi alat ukur yang biasanya menggunakan kuesioner. Cara yang digunakan untuk menguji reliabilitas kuesioner adalah dengan menggunakan Rumus Koefisien CronbachAlpha.Metode yang dipakai dalam pengujian reliabilitas adalah dengan menggunakan metode Cronbach Alpha yang dimana satu variable dianggap reliable jika cronbach alpha $\geq 0,6$.

Dari tabel diatas dapat diketahui bahwa masing-masing variabel yaitu kompensasicronbachalpha0.911, lingkungan kerjacronbachalpha0.862, disiplin kerjacronbachalpha0.910 dan kinerja karyawancronbachalpha0.870, diperoleh koefisien Alpha lebih besar yaitu dari 0,60. Dengan demikian, maka hasil uji reliabilitas terhadap keseluruhan variabel adalah reliabel sehingga untuk selanjutnya item-item pada masing-masing konsep variabel tersebut layak digunakan sebagai alat ukur.

Uji Normalitas

One-Sample Kolmogorov-Smirnov Test

\begin{tabular}{|c|c|c|c|c|c|}
\hline & & Kompensasi & Lingkungan Kerja & Disiplin Kerja & Kinerja Karyawan \\
\hline \multicolumn{2}{|l|}{$\mathrm{N}$} & 46 & 46 & 46 & 46 \\
\hline Normal & Mean & 66.7391 & 67.2391 & 59.7609 & 61.1522 \\
\hline Parameters ${ }^{\mathrm{a}, \mathrm{b}}$ & Std. Deviation & 6.63805 & 7.13110 & 7.40926 & 6.59619 \\
\hline Most Extreme & Absolute & .079 & .091 & .080 & .105 \\
\hline Differences & Positive & .062 & .091 & .080 & .105 \\
\hline & Negative & -.079 & -.067 & -.068 & -.090 \\
\hline Test Statistic & & .079 & .091 & .080 & .105 \\
\hline Asymp. Sig. (2- & tailed) & $.200^{\mathrm{c}, \mathrm{d}}$ & $.200^{\mathrm{c}, \mathrm{d}}$ & $200^{\mathrm{c}, \mathrm{d}}$ & $.200^{\mathrm{c}, \mathrm{d}}$ \\
\hline
\end{tabular}

Uji normalitas digunakan untuk melihat normalitas model regresi. Model regresi yang baik adalah yang memiliki distribusi normal atau mendekati normal.Pengujian dilakukan dengan analisa grafik, yaitu dengan melihat grafik normal probality plot.Berikut ini hasil uji normalitas dengan menggunakan grafik normal p-plot: 


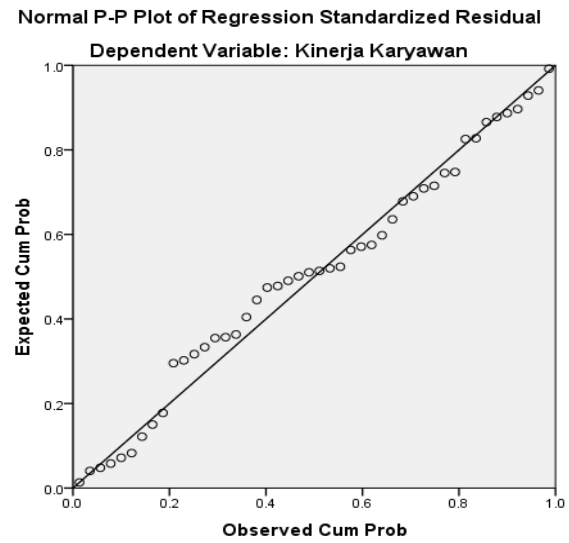

Pada gambar diatas peneliti melakukan uji normalitas dengan P-P Plot yaitu kompensasi, lingkungan kerja, dan disiplin kerja terhadap kinerja karyawan. Berdasarkan hasil pengujian normalitas diatas dapat diketahui bahwa terhadap titik-titik menyebar disekitar garis diagonal, serta penyebarannya mengikuti arah garis diagonal, maka dapat disimpulkan bahwa model regresi ini layak dipakai karena memenuhi asumsi normalitas.

\section{Heteroskedastisitas}

Menurut priyatno (2014:147)heteroskedastisitas adalah varian residual yang tidak sama pada semua pengamatan di dalam model regresi. Regresi yang baik seharusnya tidak terjadi heteroskedastisitas.

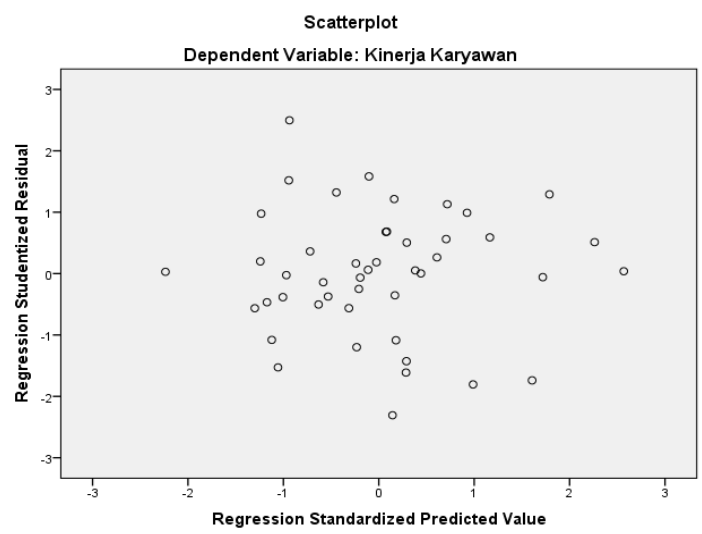

Dari gambar tersebut terlihat titik-titik menyebar secara acak dan tidak membentuk suatu pola tertentu yang jelas, serta tersebar baik di atas maupun di bawah angka 0 (nol) pada sumbu $\mathrm{Y}$, hal ini berarti tidak terjadi heteroskedastisitas sehingga model regresi layak digunakan untuk memprediksi kinerja karyawan berdasarkan masukan atas variabel kompensasi, lingkungan kerja dan disiplin kerja.

\section{Uji Multikolinieritas}

Ujimultikolonieritas dapat dilihat dari nilai tolerance dan nilai Variance Inflation Factor (VIF). Bila nilai VIF lebih kecil dari 10 dan nilai toleransinya di atas 0,1 atau $10 \%$ maka dapat disimpulkan bahwa model regresi tersebut tidak terjadi multikolonieritas. 
Coefficients $^{\mathrm{a}}$

\begin{tabular}{|c|c|c|c|c|c|c|c|c|}
\hline \multirow{2}{*}{\multicolumn{2}{|c|}{ Model }} & \multicolumn{2}{|c|}{$\begin{array}{c}\text { Unstandardized } \\
\text { Coefficients }\end{array}$} & \multirow{2}{*}{$\begin{array}{c}\begin{array}{c}\text { Standardized } \\
\text { Coefficients }\end{array} \\
\text { Beta }\end{array}$} & \multirow[b]{2}{*}{$\mathrm{T}$} & \multirow[b]{2}{*}{ Sig. } & \multicolumn{2}{|c|}{ Collinearity Statistics } \\
\hline & & $\mathrm{B}$ & Std. Error & & & & Tolerance & VIF \\
\hline \multirow[t]{4}{*}{1} & (Constant) & 78.313 & 12.925 & & 6.059 & .000 & & \\
\hline & Kompensasi & .474 & .122 & .477 & 3.889 & .000 & .954 & 1.048 \\
\hline & $\begin{array}{l}\text { Lingkungan } \\
\text { Kerja }\end{array}$ & -.406 & .118 & -.439 & -3.447 & .001 & .885 & 1.130 \\
\hline & Disiplin Kerja & -.360 & .111 & -.404 & -3.237 & .002 & .922 & 1.085 \\
\hline
\end{tabular}

a. Dependent Variable: Kinerja Karyawan

Berdasarkan tabel di atas dapat diketahui bahwa setiap variabel memiliki nilai Tolerance tidak kurang dari 0,10 dan nilai Variance Inflation Factor (VIF) tidak lebih dari 10. Analisis ini menunjukkan bahwa tidak terdapat gejala multikolonieritas terhadap variabel penelitian.Sehingga layak untuk digunakan dalam pengujian selanjutnya.

\section{Uji Autokorelasi}

\begin{tabular}{|l|r|r|r|r|r|}
\hline Model & R & R Square & Adjusted R Square & $\begin{array}{c}\text { Std. Error of the } \\
\text { Estimate }\end{array}$ & Durbin-Watson \\
\hline 1 & $.630^{\mathrm{a}}$ & .397 & .353 & 5.304 & 2.428 \\
\hline
\end{tabular}

a. Predictors: (Constant), Disiplin Kerja, Kompensasi, Lingkungan Kerja

b. Dependent Variable: Kinerja Karyawan

Nilai DU dan DL dapat diperoleh dari tabel statistik Durbin Watson, dengan $n=46$, dan $\mathrm{k}=3$ didapat nilai $\mathrm{DL}=1.201$ dan $\mathrm{DU}=1.474$. Jadi nilai $4-\mathrm{DU}=2.526$ dan $4-\mathrm{DL}=2.799$. Dari output di atas dapat diketahui nilai Durbin Watson sebesar 2.428. Karena nilai DW terletak antara DU dan 4-DU $(1.474<2.428<2.526)$, hasilnya tidak ada autokorelasi pada model regresi.

\section{Persamaan Regresi Linier Berganda}

\begin{tabular}{|c|c|c|c|c|c|c|}
\hline \multicolumn{7}{|c|}{ Coefficients $^{\mathrm{a}}$} \\
\hline & & \multicolumn{2}{|c|}{ Unstandardized Coefficients } & $\begin{array}{l}\text { Standardized } \\
\text { Coefficients }\end{array}$ & \multirow[b]{2}{*}{$\mathrm{t}$} & \multirow[b]{2}{*}{ Sig. } \\
\hline \multicolumn{2}{|c|}{ Model } & $\mathrm{B}$ & Std. Error & Beta & & \\
\hline \multirow[t]{4}{*}{1} & (Constant) & 78.313 & 12.925 & & 6.059 & .000 \\
\hline & Kompensasi & .474 & .122 & .477 & 3.889 & .000 \\
\hline & Lingkungan Kerja & -.406 & .118 & -.439 & -3.447 & .001 \\
\hline & Disiplin Kerja & -.360 & .111 & -.404 & -3.237 & .002 \\
\hline
\end{tabular}

a. Dependent Variable: Kinerja Karyawan

Berdasarkan tabel dapat diketahui persamaan regresi yang terbentuk adalah:

$\mathbf{Y}=\mathbf{a}+\beta_{1} \mathbf{X}_{1}+\beta_{2} \mathbf{X}_{2}+\beta_{3} \mathbf{X}_{3}$

$$
Y=78.313+0,474 X 1+(-0,406) X 2+(-0,360) X 3
$$

Dari persamaan tersebut dapat dijelaskan bahwa:

a. Nilai constantasebesar 78.313 diartikan bahwa ketika variabel kompensasi, lingkungan kerja dan disiplin kerja konstan, maka variabel kinerja karyawan akan mengalami kenaikan/meningkat sebesar 78.313 .

b. Nilai koefisien regresi variabel kompensasi $\left(\mathrm{X}_{1}\right)$ sebesar 0.474 , diartikan bahwa jika 
kompensasi mengalami peningkatan (1) sedangkan lingkungan kerja dan disiplin kerja konstan atau tidak ada (sebesar 0), maka kinerja karyawan akan mengalami peningkatan sebesar 0.474 .

c. Nilai koefisien regresi variabel lingkungan kerja $\left(\mathrm{X}_{2}\right)$ sebesar -0.406 , diartikan bahwa jika lingkungan kerja mengalami peningkatan (1) sedangkan kompensasi dan disiplin kerja konstan atau tidak ada (sebesar 0), maka kinerja karyawan akan mengalami peningkatan sebesar 0.406 .

d. Nilai koefisien regresi variabel disiplin kerja $\left(\mathrm{X}_{3}\right)$ sebesar -0.360 , diartikan bahwa jika disiplin kerja mengalami peningkatan (1) sedangkan kompensasi dan lingkungan kerja atau tidak ada (sebesar 0), maka kinerja karyawan akan mengalami peningkatan sebesar 0.360.

\section{Uji t (Uji Hipotesis Secara Parsial)}

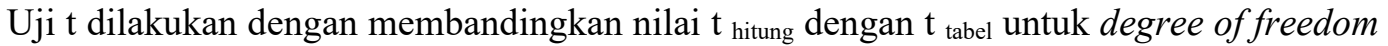
$(\mathrm{df})=\mathrm{n}-\mathrm{k}-1$, dalam hal ini (n) merupakan jumlah sampel dan (k) merupakan jumlah variabel independent dalam penelitian dan 1 adalah jumlah variabel dependent. Pada penelitian ini jumlah sampel $(\mathrm{n})=46$, maka besarnya df dapat dihitung $46-3-1=42$, dengan $\mathrm{df}=42 \mathrm{dan}$ alpha 0.05 didapat $\mathrm{t}$ tabel $=1.682\left(\right.$ dengan melihat $\mathrm{t}_{\text {tabel }}$ pada $\left.\mathrm{df}=42\right)$.

\begin{tabular}{|l|l|l|l|l|l|}
\hline Variabel Bebas & $\mathrm{t}$ hitung & Kondisi & $\mathrm{t}$ table & Sig & Keterangan \\
\hline Kompensasi & 3.889 & $>$ & 1.682 & 0.000 & Ho ditolak \\
\hline Lingkungan Kerja & -3.447 & $<$ & 1.682 & 0.001 & Ho ditolak \\
\hline Disiplin Kerja & -3.237 & $<$ & 1.682 & 0.002 & Ho ditolak \\
\hline
\end{tabular}

a. Variabel kompensasi nilai $t_{\text {hitung }}>\mathrm{t}_{\text {tabel }}$ dan nilai signifikan 0.000 maka $\mathrm{H}_{\mathrm{o}}$ ditolak, maka terdapat pengaruh signifikan

b. Variabel lingkungan kerja nilai $t_{\text {hitung }}<t_{\text {tabel }}$ dan nilai signifikan 0.001 maka $\mathrm{H}_{\mathrm{o}}$ ditolak, maka terdapat pengaruh signifikan

c. Variabel disiplin kerja nilai $t_{\text {hitung }}<t_{\text {tabel }}$ dan nilai signifikan 0.021 maka $\mathrm{H}_{\mathrm{o}}$ ditolak, maka terdapat pengaruh signifikan

\section{Uji F (Uji Simultan)}

\begin{tabular}{|ll|r|r|r|r|r|}
\hline Model & & Sum of Squares & \multicolumn{1}{|c|}{ Df } & Mean Square & \multicolumn{1}{c|}{ F } & Sig. \\
\hline 1 & Regression & 776.381 & 3 & 258.794 & 9.199 & $.000^{\mathrm{b}}$ \\
& Residual & 1181.554 & 42 & 28.132 & & \\
& Total & 1957.935 & 45 & & & \\
\hline
\end{tabular}

a. Dependent Variable: Kinerja Karyawan

b. Predictors: (Constant), Disiplin Kerja, Kompensasi, Lingkungan Kerja

Dari data tabel diatas, diketahui dari hasil uji ANOVA nilai $F_{\text {hitung }}$ sebesar 9.199. Nilai $F_{\text {tabel }}$ dapat dicari dengan melihat kolom df, yaitu dengan df pembilang $=3$ df penyebut $=42$ sedangkan $a=5 \%$, maka diperoleh nilai $F_{\text {tabel }}$ sebesar 2.827. Nilai $F_{\text {hitunglebih besar }}$ dibandingkan nilai $F_{\text {tabel }}$, dengan demikian variabel kompensasi, lingkungan kerja dan disiplin kerja secara simultan berpengaruh terhadap kinerja karyawan pada PT. Strategi Inisiatif Media.

\section{Uji Koefisien Determinasi $\mathbf{R}^{2}$}




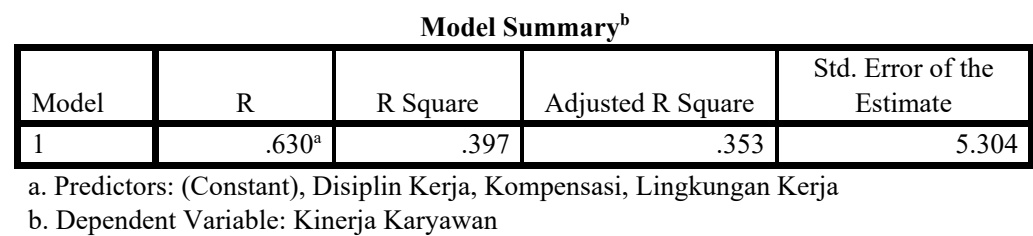

Hasil perhitungan regresi dapat diketahui bahwa koefisien determinasi (adjusted $\mathrm{R}^{2}$ ) yang diperoleh sebesar 0.353 . Hal ini berarti $35.3 \%$ variansi kinerja karyawan dapat dijelaskan oleh variabel kompensasi, lingkungan kerja dan disiplin kerja sedangkan sisanya sebesar $64.7 \%$ diterangkan oleh variabel lain yang tidak diajukan dalam penelitian ini.

\section{Pembahasan}

\section{Pengaruh Kompensasi Terhadap Kinerja Karyawan pada PT. Strategi Inisiatif Media}

Menurut Singodimedjo dalam Sutrisno (2016:182), mengemukakan kompensasi adalah semua balas jasa yang diterima seorang karyawan dari perusahaanya sebagai akibat dari jasa/tenaga yang telah diberikan pada perusahaan tersebut. Hasil pengujian hipotesis $\left(\mathrm{H}_{1}\right)$ diketahui bahwa variabel kompensasi $\left(\mathrm{X}_{1}\right)$ mempengaruhi variabel kinerja karyawan $(\mathrm{Y})$ dengan nilai $t_{\text {hitung }}$ positif untuk variabel kompensasi 3.889 lebih besar dari nilai $t_{\text {tabel }}$ sebesar 1.682 dengan tingkat signifikansi $=0,000>\alpha=0,05$ dengan demikian menolak $\mathrm{Ho}_{1}$ dan menerimaHa ${ }_{1}$. Artinya bahwa kompensasi berpengaruh positif yang signifikan terhadap kinerja karyawan pada PT. Strategi Inisiatif Media.

Dalam hasil penelitian ini dapat diketahui bahwa kompensasi merupakan biaya utamaatas keahlian atau pekerjaan dan kesetiaan dalam tujuan perusahaan.Kompensasi menjadi alasan utama mengapa kebanyakan orang mencaripekerjaan.Kompensasi finansial terdiri darikompensasi tidak langsung dan langsung.Kompensasi langsung terdiri dari pembayaran pegawai berupagaji dan insentif.Kompensasi tidak langsung dapat berupa tunjangan, fasilitas dan berbagai macam asuransi. Apabila kompensasi tersebut berjalan dengan baik maka kinerja karyawan dalam melaksanakan pekerjaanakan meningkat.Hasil penelitian ini sesuai dengan penelitian sebelumnya yang dilakukan oleh Adolfina (2016) yaitu kompensasi memiliki pengaruh secara positif dan signifikan terhadap kinerja karyawan pada Dinas Pendapatan Daerah Kota Manado.

\section{Pengaruh Lingkungan Kerja Terhadap Kinerja Karyawan pada PT. Strategi Inisiatif Media}

Hasil penelitian Rahmawanti, dkk.(2014) menyatakan agar dapat mencapai tujuan, perusahaan harus menciptakan lingkungan kerja yang baik secara fisik dan non fisik.Hasil pengujian hipotesis $\left(\mathrm{H}_{2}\right)$ diketahui bahwa variabel lingkungan kerja $\left(\mathrm{X}_{2}\right)$ mempengaruhi variabel kinerja karyawan $(\mathrm{Y})$ dengan nilai $t_{\text {hitung }}$ negatif untuk variabel lingkungan kerja -3.447 dan nilai $t_{\text {tabel }}$ sebesar 1.682 dengan tingkat signifikansi $=0,001<\alpha=0,05$. Artinya bahwa lingkungan kerja berpengaruh negatif terhadap kinerja karyawan.Hasil penelitian ini sesuai dengan penelitian sebelumnya yang dilakukan oleh Ni Luh Tesi Riani (2917)hasil penelitian membuktikan bahwa lingkungan kerja memiliki pengaruh negatif dan signifikan terhadap kinerja karyawan Dikatakan signifikan karena mampu melaksanakan pekerjaan berdasarkan instruksi dari atasan dan hubungan terhadap karyawan harus berjalan harmonis. 


\section{Pengaruh Disiplin Kerja Terhadap Kinerja Karyawan pada PT. Strategi Inisiatif Media}

Menurut Dr. Malayu S. P. Hasibuandalam R. Supomo dan Eti Nurhayati (2018:133), disiplin kerja adalah kesadaran atau kesediaan seseorang menaati semua peraturan perusahaan dan norma-nora social yang berlaku.Hasil pengujian hipotesis $\left(\mathrm{H}_{3}\right)$ diketahui bahwa disiplin kerja $\left(\mathrm{X}_{3}\right)$ mempengaruhi variabel kinerja karyawan $(\mathrm{Y})$ dengan nilai thitung negative untuk variabel disiplin kerja -3.237 dan nilai $t_{\text {tabel }} 1.682$ dengan tingkat signifikansi $=0,002<\alpha=0,05$ dengan demikian menolak $\mathrm{Ho}_{3}$ dan menerima $\mathrm{Ha}_{3}$. Artinya bahwa disiplin kerja berpengaruh negatif terhadap kinerja karyawan. Hal penelitian ini sesuai dengan penelitian sebelumnya oleh Wahyu Tri Gunandi (2016) disiplin kerja memiliki pengaruh negatif terhadap kinerja karyawan.

\section{Pengaruh Kompensasi, Lingkungan Kerja dan Disiplin Kerja Terhadap Kinerja Karyawan pada PT. Strategi Inisiatif Media}

Uji $\mathrm{F}$ pada dasarnya menunjukkan apakah semua variabel bebas kompensasi $\left(\mathrm{X}_{1}\right)$, lingkungan kerja $\left(\mathrm{X}_{2}\right)$, dan disiplin kerja $\left(\mathrm{X}_{3}\right)$ yang dimasukkan dalam model mempunyai pengaruh secara bersama-sama terhadap variabel dependen kinerja karyawan (Y).

Hasil pengujian signifikansi simultan (uji F) diketahui bahwa $F_{\text {hitung }}>F_{\text {tabel }} 9.199$ lebih besar dari 2.827 dan tingkat signifikansi $0,000<0,05$ karena tingkat signifikansi pada uji Anova sebesar 0,000 dibawah 0,05 dan $\mathrm{F}_{\text {tabel }}<\mathrm{F}_{\text {hitung }}$ maka dapat disimpulkan bahwa Ho ditolak dan Ha diterima, artinya terdapat pengaruh secara bersama-sama dan signifikan terhadap variabel kompensasi, lingkungan kerja dan disiplin karyawan terhadap kinerja karyawan, sehingga hal ini berarti bahwa variabel kinerja karyawan dapat dijelaskan secara signifikan oleh kompensasi, lingkungan kerja, dan disiplin kerja.

\section{PENUTUP}

\section{Kesimpulan}

Penelitian ini dilakukan untuk mengetahui pengaruhkompensasi, lingkungan kerja dan disiplin kerja terhadap kinerja karyawan PT. Strategi Inisiatif Media dapat disimpulkan sebagai berikut:

a. Terdapat pengaruh kompensasi terhadap kinerja karyawanpada PT. Strategi Inisiatif Media, hal ini dapat ditunjukkan dengan nilai $t_{\text {hitumg }}$ sebesar $3.889>t_{\text {tabel }} 1.682$ dan nilai signifikansi $=$ $0,000>\alpha=0,05$ dengan demikian menolak $\mathrm{Ho}_{1}$ dan menerima $\mathrm{Ha}_{1}$.

b. Terdapat pengaruh lingkungan kerja terhadap kinerja karyawan pada PT. Strategi Inisiatif Media, hal ini dapat ditunjukkan dengan nilai $\mathrm{t}_{\text {hitumg }}$ sebesar $-3889<\mathrm{t}_{\text {tabel }} 1.682$ dan nilai signifikansi $=0,0001>\alpha=0,05$ dengan demikian menolak $\mathrm{Ho}_{2}$ dan menerima $\mathrm{Ha}_{2}$.

c. Terdapat pengaruh disiplin kerja terhadap kinerja karyawan pada PT. Strategi Inisiatif Media, hal ini dapat ditunjukkan dengan nilai $\mathrm{t}_{\text {hitumg }}$ sebesar $-3.237<\mathrm{t}_{\text {tabel }} 1.682$ dan nilai signifikansi $=0,0002>\alpha=0,05$ dengan demikian menolak $\mathrm{Ho}_{3}$ dan menerima $\mathrm{Ha}_{3}$.

d. Kompensasi, lingkungan kerja, disiplin kerja pada PT. Strategi Inisiatif Media secara simultan atau bersama-sama berpengaruh signifikan terhadap kinerja karyawan. Hal ini dapat ditunjukkan dengan nilai $F_{\text {hitung }} 9.199>\mathrm{F}_{\text {tabel }} 2.827$ dan nilai signifikan $0.000<0.05$. 


\section{DAFTAR PUSTAKA}

Arif Yusuf Hamali. 2016. Pemahaman Manajemen Sumberdaya Manusia, CAPS, Jakarta.

Donni Juni Prians. 2017. Manajemen Kinerja Kepegawaian, CV Pustaka Setia, Bandung.

Duwi Priyatno. 2014. SPSS 22, CV ANDI, Yogyakarta.

Edy Sutrisno. 2016. Manajemen Sumber Daya Manusia, Kencana, Jakarta.

Eko, Widodo Suparno. 2015. Manajemen Pengembangan Sumber Daya Manusia, Pustaka Pelajar, Yogyakarta.

Gary Dessler. 2013. Manajemen Sumber Daya Manusia, PT Indeks, Jakarta.

Ghozali. 2013. Aplikasi Analisis Multivariate dengan Program SPSS, Badan Penerbit Univer Diponegoro, Semarang.

Hasibuan. 2014. Manajemen Sumber Daya Manusia, PT Bumi Aksara, Jakarta.

Jusuf Soewadji. 2012. Pengantar Metodologi Penelitian, Wacana Media, Jakarta.

Kasmir. 2016. Manajemen Sumber Daya Manusia, PT Raju Grafindo Persada, Jakarta.

Lijan Poltak Sinambela. 2016. Manajemen Sumber Daya Manusia, PT Bumi Aksara, Jakarta.

Mathis, Jackson. 2012. Manajemen Sumber Daya Manusia, Salemba Empat, Jakarta.

Nuraini. 2013. Manajemen Sumber Daya Manusia, Yayasan Arnisyam, Pekan Baru.

Prabu Mangkunegara. 2013. Manajemen Sumber Daya Manusia Perusahaan, PT Remaja Rosdakarya, Bandung.

Sedarmayanti. 2017. Manajemen Sumber Daya Manusia, PtT Rafika Aditima, Bandung.

Sugiono. 2012. Metodologi Penelitian Bisnis, Alfabeta, Bandung.

Supomo, Eti. 2018. Pengantar Manajemen, Yrama Widya, Bandung.

Wibowo. 2016. Manajememen Kinerja, Raja Grafindo Persada, Jakarta.

Wiratna Sujarwani. 2014. Metodologi Penelitian, Pustaka Baru Press, Yogyakarta.

Adolfina. 2016. Pengaruh Lingkungan Kerja, Kompensasi dan Beban Kerja terhadap Kinerja Karyawan pada Dinas Pendataan Daerah Kota Manado, Jurnal EMBA, Vol. 4, No. 2.

Diah Indriani Suwondo dan Eddy Madiono Sutanto. 2015. Hubungan Lingkungan Kerja, Disiplin Kerja dan Kinerja Karyawan., Jurnal Manajemen dan Kewirausahaan, Vol. 17, No. 2.

Friski Lakoy, Gainer. 2013. Motivasi Kerja, Kompensasi, Pengembangan Karir terhadap Kinerja Karyawan Pegawai Badan Penanggulangan Bencana Daerah Provinsi Sulawesi Utara, Jurnal EMBA, Vol. 1, No. 4.

Heny Sidanti. (2015) . Pengaruh Lingkungan Kerja,Disiplin kerja Dan Motivasi Kerja Terhadap Kinerja Pegawai Negeri Sipil Di Sekertariat DPRD Kabupaten Madiun, Jurnal JIBEKA, Vol. 9. 44-53.

Joyce Lapian. 2015. Pengaruh Disiplin Kerja, Penempatan Kerja dan Lingkungan Kerja Terhadap Kinerja Pegawai pada Badan Pelayanan Perizinan Terpadu Kota Manado, Jurnal Riset Ekonomi, Manajemen, Bisnis dan Akuntansi, Vol. 13, No. 3.

Ni Luh Tesi Riani. 2017. Beban Kerja dan Lingkungan Kerja Non Fisik terhadap Turnover Intention Karyawan, Jurnal Manajemen Unud, Vol. 6, No. 11.

Paiti Sulistiawati. 2015. Pengaruh Kompensasi Dan Lingkungan Kerja Terhadap Kinerja Pegawai Pada Balai Pendidikan Dan Pelatihan Keagamaan Manado, Jurnal Riset Ekonomi, Manajemen, Bisnis Dan Akuntansi, Vol. 3, No. 3.

Suharyanto. 2014. Pengaruh Kompensasi Dan Lingkungan Kerja Terhadap Kinerja Karyawan Pada Divisi QIP PT. GSI Cianjur, Jurnal Bisnis Dan Manajemen, Vol. 3, No. 2.

Yanti Komala Sari. 2014. Pengaruh Kepemimpinan, Motivasi, dan Disiplin Kerja terhadap Kinerja Karyawan PT. Patra Komala di Dumai, Jurnal Tepa Manajemen Bisnis, Vol. 6, No. 2. 